This is the author's version of a work that was submitted to / accepted for publication. To cite this article: Hemming, P. J. 2007. Renegotiating the primary school: children's emotional geographies of sport, exercise and active play. Children's Geographies 5(4), pp. 353-371. (10.1080/14733280701631817)

Renegotiating the Primary School: Children's Emotional Geographies of Sport, Exercise and

\title{
Active Play
}

Peter J. Hemming, School of Geography and School of Sociology \& Social Policy, University of Leeds, Woodhouse Lane, Leeds, LS2 9JT, UK. E-mail: p.j.hemming06@leeds.ac.uk

\begin{abstract}
The current UK policy concern with children's health has led to primary school practices of sport, exercise and active play aimed, in particular, at constructing children's bodies as 'healthy'. Qualitative explorations of children's own values and experiences however, reveal that their understandings of sport in school differ considerably from its potential to be healthy, instead emphasising emotional geographies of pleasure and enjoyment. This article aims to develop a better understanding of children's ability to modify and reconstitute discursive corporeal regimes through their own agency, thus highlighting the fluid nature of the primary school as an institution. Adult discourses and children's bodily challenges to these mingle and intersect, creating spaces of competing values and discourses that work to transform and renegotiate the primary school. Although this article focuses particularly on the UK context, the findings will be relevant for any country in which child obesity is of current concern for social and education policy.
\end{abstract}

Keywords: Children, health, sport, bodies, emotions, school 


\section{Introduction}

Sport, exercise and active play in school are currently at the centre of UK Government efforts to reduce child obesity and increase the number of people participating in sport and exercise generally. Government figures show that $14 \%$ of children aged $2-10$ in England were classified as obese in 2004 and, if current trends continue, this figure is projected to rise to $20 \%$ by 2010 (Department of Health, 2006). The issue has gained increasing prominence in popular and political forums, with the involvement of high-profile celebrities such as Jamie Oliver, and recognition of the need to tackle the problem at policy level. The Government White Paper (2004) 'Choosing Health: Making healthy choices easier', set two of its six over-arching priorities as reducing child and adult obesity, by improving diet and nutrition and increasing exercise levels to reduce the risk of chronic disease caused by inactivity. The 2004 Children Act and 'Every Child Matters' agenda has also given children's health across all UK Government services an increased emphasis, with a commitment to help children to 'Be Healthy' the first of its stated aims and outcomes ('Every Child Matters' Website).

In the last few years, there have been a whole host of school-based health initiatives launched in the UK that have effectively shifted responsibility for children's health away from families and individuals and more towards the school. The 'National Healthy Schools Programme' launched in 1999 and the 'Food in Schools Programme' launched in 2001 are two examples of schemes that have encouraged schools to promote good health to children through eating and fitness practices. In addition, the 'National PE, School Sport and Club Links Strategy' began in 2003 and aims to enhance sport opportunities for 5-16-year-olds 
and offer all children at least four hours of weekly sport by 2010 . The strategy has helped to encourage new practices in schools such as greater emphasis on PE teaching, expansion of after-school sports clubs and development of better quality playground provision to encourage active play (see 'National PE Strategy' Website). Since 2004, schools have been legally required to work towards improvement in the development of pupils' 'healthy eating', 'personal, social and health education', 'physical activity' and 'emotional health and well-being', and are judged by OFSTED on their progress (Department of Health, 2005). Similar Government grants and initiatives aimed at improving health in schools can also be found in many other Western contexts, either at the federal or the state level (e.g. see US Department of Education Website; Victoria (Australia) Department of Education \& Training Website; Ontario (Canada) Ministry of Education Website).

All of these initiatives may be viewed as examples of a particular form of 'governmentality' engendered through neo-liberal discourses of 'freedom' and 'individualism' (see Foucault, 1988, cited in Rose-Redwood, 2006, p. 474). Through these discourses, neoliberal governments work to shape subjects into self-regulating and responsible citizens in order to achieve power over populations (Joyce, 2003). Health programs and initiatives in the UK therefore position children as in need of education and support in order to make the 'correct' health and lifestyle decisions. Rawlins (in press) argues that these messages cannot be separated from the New Labour Government's notions of the 'good citizen' and the idea that individuals need to make their choices for the good of society as well as the self. Despite the attempted 'totalizing' nature of such discourses, Raco (2003) argues that in reality, government agendas are 'contradictory, contested and influenced by the actions of subjects who respond to government agendas in a variety of ways' (Raco, 2003, p. 91). Government 
health rhetoric may therefore overlook the complex processes bywhich individual health decisions are made in the context of uncertain and contradictory information from friends, family, school and state (Wright and Burrows, 2004; Rawlins, in press).

In this article, I explore the issue of sport, exercise and active play in the primary school, in the context of the UK national policy concern for health outlined above. In so doing, I draw on and contribute to the academic literatures on children's geographies and institutional geographies. The aim of the article is to illustrate how a focus on children's agency in the primary school context can not only help to broaden our understanding of children as social actors, but also further highlight the fluid and dynamic nature of institutional spaces. By gaining insight into children's experiences and emotions within the institutional spaces of the PE lesson, playground and school as a whole, I aim to develop a deeper understanding of children's ability to modify and reconstitute discursive corporeal regimes through their own agency. I will argue that through bodily practice and emotional expression, many children create alternative discourses that mingle and intersect with dominant ones, creating spaces of competing values and discourses. These work to both challenge hegemonic ideologies of childhood and transform and renegotiate the primary school.

I will begin the article with a discussion of the nature of institutions and the theoretical potential for children to renegotiate the structure of the school through their own agency and use of discourse. After outlining the methodological nature of the study, I will explore how school and government attempts to construct 'healthy bodies' are at odds with the way that many children perceive sport, exercise and active play in terms of their emotional experiences of pleasure and enjoyment (or lack of them). In the next section, I will discuss 
the way that some children actively challenge dominant discursive regimes in school, through the use of their own bodily practices in subverting the purpose of sport activities. Finally, I will argue that these practices, along with the alternative ways that children value sport and active play, result in a transformation of the school structure itself.

\section{Children, Institutions and Agency}

Over the last decade, children's geographers have made significant progress in contributing to our knowledge of the nature of children's agency within the spaces of the home and family (e.g. Sibley, 1995a; Valentine, 1997; McNamee, 1998; Robson and Ansell, 2000; Holloway and Valentine, 2001) and spaces of play and recreation (e.g. Matthews et al., 2000; Punch, 2000; Karsten, 2003; Thompson and Philo, 2004; Ferré et al., 2006). To date, however, there has been less interest from geographers into the way that children behave as active agents within contemporary institutional contexts, such as the primary school (exceptions include Fielding, 2000; Holt, 2004). Studies that have considered children and bodies in school spaces have tended to focus on secondary schools rather than primary schools (e.g. Hyams, 2000; Holloway and Valentine, 2003; Evans, 2006). This has meant that links between children's geographies and institutional geographies in the primary school context have so far remained under-developed and in need of further exploration.

Geography's previous preoccupation with the spatial distribution and impact of institutions has now shifted to an interest in their internal geographies, where the role of space inside the institution for constituting and mediating social relations is the primary focus. One result of this shift is that institutions are now increasingly seen as fluid and dynamic, rather than 
static and fixed entities (Philo and Parr, 2000). Recent work on institutions in geography has therefore explored the way that social-spatial processes ricochet back onto the structure of the institution itself, thereby manipulating and transforming space and place (e.g. Tooke, 2000; Saugeres, 2000). In this way, the institution can be seen as something that is made or accomplished. Just as Massey (1999) describes how space is constantly made and remade through embedded social practices and relations, so the institution as a social space is also continually in the process of 'becoming'.

The institution as a dynamic entity is constructed and reconstructed through the socialspatial processes that take place within it. As Saugeres (2000) points out, 'individuals are not passive recipients of [. . . ] structural constraints, they are themselves active agents in the reproduction and negotiation of institutional reality and structures' (Saugeres, 2000, p. 589). The institution therefore occupies an intermediate space between individual interaction at the micro-level and societal structural properties at the macro-level. Through Bourdieu's (1990) habitus, internalised dispositions that mediate between the micro and the macro-level, structural practice is not only reinforced and reproduced by social agents but is also reconstituted by negotiation and resistance. This is because in enacting the habitus, individuals are able to make their own choices and adopt their own strategies, thereby strengthening as well as renegotiating the dominant ideology inherent to the functioning of the institution (see also Saugeres, 2000). In this sense, ideology is taken to refer to the system of ideas facilitating dominant interests within the institution and wider society (see Thompson, 1981).

Central to the processes of institutional construction and reconstruction is the concept of 
discourse. Discourse can be defined as 'a specific series of representations, practices and performances through which meanings are produced, connected into networks and legitimised' (Gregory, 2000, p. 180). It is through discourse that individuals are able to reinforce or challenge dominant ideologies (Thompson, 1984). Discourses are not homogeneous or unified, but open to contestation, allowing for the co-existence of competing discourses between interest groups that can either support or transform hegemonic ideology (Barnes and Duncan, 1992). It is therefore through the medium of discourse that individuals are able to challenge institutional practices, and hence dominant ideologies, through the expression of competing values (e.g. see Boden, 1994; O'Neill and Gibson-Graham, 1999). Institutional space therefore acts as a forum for competing values and discourses that may result in the transformation of the institution itself.

Given that the new social studies of childhood have demonstrated children's social agency and their ability to contest and renegotiate the ways in which adult power operates in space (see Prout and James, 1997; Holloway and Valentine, 2000), this allows for the possibility that children may themselves be involved in renegotiating and transforming institutional space. Discursive regimes in the primary school may, therefore, be challenged when children use and reconstruct their bodies in alternative ways to those envisaged. Through their bodily actions and expressions of emotion, children may reformulate regimes of discourses and values on their own terms.

Previous studies have demonstrated how competing notions of gender and disability in the school construct the classroom as a permeable accomplishment and as a forum for cultural discord (Holloway et al., 2000; Holt, 2004). Children in these studies negotiated their way 
through dominant understandings of identity within the multi-layered nature of the school institution, thus creating alternative discourses that intersected with hegemonic ones within school spaces. These studies demonstrate how children's agency does indeed have the potential to challenge corporeal regimes and constructions of social identity, thereby renegotiating institutional spatialities and structures.

In this article, I will argue that many children contest school and policy constructions of the 'healthy body' through corporeal and emotional expressions of alternative values that emphasise fun, enjoyment and pleasure. This will further highlight children's ability to engage with the fluid nature of the school as an institution through their own agency, particularly emphasising the role that emotions have in influencing these processes of transformation.

\section{The Study}

The data for this article is taken from a qualitative case study on health, sport, exercise and active play in a large mixed junior school (children aged 7-11), situated in a residential suburb of an urban area in the Midlands region of England. For the purposes of this article, I have given the school the pseudonym of 'Meadow Junior'. The study focused on one particular class of Year 5 pupils (9-10-year-olds), although some of the playground and whole school observations included pupils from the rest of the school. The school was chosen as an 'instrumental case study' because of its varied physical contexts available for sport and active play. The qualitative case study has the advantage of being able to 'retain the holistic and meaningful characteristics of real-life events' (Yin, 2003, p. 2), and allows for 
a depth of understanding of social processes. The limits of the small sample should, however, be acknowledged and the study may be viewed as a foundation for further research with larger samples.

The research included a range of qualitative methods including participant observation, semi-structured interviews, individual drawings and group photography. A combination of interpretive and creative 'child-centred' participatory methods was employed to allow for a 'triangulation' or 'crystallization' of perspectives (see Richardson, 1994). Participant observation was used to build up a detailed understanding of child-child and child-adult interactions in school sport and play contexts (recorded in a research diary), while working as a classroom volunteer. This occurred alongside semi-structured 'research conversations', that were undertaken with pairs of children, hence giving children the confidence to talk about their experiences of sport and active play and reducing uneven adult-child power relations (see Mayall, 2000). These lasted between 20 and 30 minutes with 23 children (10 pairs and a group of 3), chosen to reflect a gender balance in the class. They involved the use of visual images to stimulate ideas about exercise and different spaces around the school, as well as traffic light cards for children to control when the interview would start (green), pause (yellow) and stop (red) (see Alderson and Morrow, 2004).

The creative 'child-centred' participatory methods were aimed at eliciting children's perceptions and ideas regarding the concept of 'health'. The individual drawing activity was based on ideas from Wetten and McWhirter (1998) and Burrows and Wright (2004), but was given extra relevance for children by using the popular 'Mr. Men' and 'Little Miss' children's book series by Roger Hargreaves. Children were asked to draw a 'Mr. Healthy' and 'Mr. 
Unhealthy' or the 'Little Miss' equivalents, with a setting and other relevant items surrounding the pictures, and labels to clarify the content of the drawings. For the group photography activity, children were asked to take photos of five 'healthy' and five 'unhealthy' places around the school using disposable cameras. They were asked to make these decisions based on particular characteristics of the places in question, or activities that took place within them and record the reasons for their choices. The activity was based on ideas from Scratz and Steiner-Loffler (1998), although with health as its primary focus. These methods were analysed using thematic categories along with the ethnographic data in order to ensure consistency for data integration (see Mason, 2002).

Research involving children necessitates specific ethical considerations, and appropriate adaptations to the usual ethical procedures, in order to manage risk effectively for child participants (e.g. see Alderson, 1995, 2000, 2004; Matthew et al., 1998; Valentine, 1999a; Lindsay, 2000; Alderson and Morrow, 2004). To this end, children were fully involved in the consent process, informed through child-friendly information leaflets, visual presentations and through discussion and questions. Interviewees were invited to choose pseudonyms to replace their real names and maintain the anonymity of their responses, and all taped conversations took place in private.

\section{School's Construction of the 'Healthy Body'}

The institution has historically sought to 'restrain, control, treat, "design" and "produce" particular and supposedly improved versions of human minds and bodies' (Philo and Parr, 2000 , p. 513). As such, the school as an institution makes use of Foucault's $(1977,1979)$ 
'disciplinary mechanisms' and 'biopower' (subtle routines and discourses used to exert power over bodies) to construct child bodies of 'docility-utility': bodies of compliance but also of productivity. Foucault (1972) describes discourses as 'practices that systematically form the objects of which they speak' (Foucault, 1972, p. 49), so in this sense, institutional discursive structures may actually produce concepts or effects (Barrett, 1991; Mills, 1997). In the school, therefore, minute details and subtle routines (such as school timetables; classroom arrangements; curriculum organisation) can construct bodies in particular ways reflecting these 'microphysics' of power. ${ }^{1}$ Children's bodies can thus be seen as social spaces, upon which cultural values and norms are inscribed (see Grosz, 1993).

In response to national policy requirements, Meadow Junior was in the business of constructing 'healthy' bodies. On the 'About Us' section of the school website, the school boasts about its 'Health Promoting Schools' award and the school prospectus includes a section on the importance of encouraging healthy lifestyles as part of the curriculum. Like all state primary schools, Meadow Junior was involved in the 'National Healthy Schools Programme', and the 'National PE, School Sport and Club Links Strategy' and as such, physical education was being developed further in school with a wide range of sports-based extra-curriculum clubs offered, including boys' football, girls' football, netball, hockey, rugby and country dancing. The playground had been provided with 'healthy play' equipment to promote active play and plans were in place to smooth over the playground surface, with lines added for games such as hopscotch. Other recent health orientated developments in the school included greater emphasis on health education, healthier school dinners and snacks and encouraging children to use water bottles in the classroom (see research diary extract below). 
After school I went to talk to the 'Healthy Schools' and school council co-ordinator. He told me that originally 'Healthy Schools' had been split into seven areas but now there were only four and it had been linked up to the 'Every Child Matters' agenda. The four areas were $P E$, food, emotional wellbeing and physical health and wellbeing. He was required to do an audit to identify where the school was in these areas and choose one area to work on as part of an action plan. The school was currently focusing on the food side of things.

(Research Diary Extract: Monday $27^{\text {th }}$ March 2006)

As the quote below from Eleanor illustrates, many children were also very aware of the school's role in promoting health alongside their families, contrasting with the work of Mayall et al. (1996) over a decade ago, when children did not consider school to be responsible for looking after their health.

ELEANOR: [. . .] The school makes sure that you drink plenty of water, washes your hands before lunch, does PE inside and outside, so outside you can do lots of runnin' about and like activities that make your hands, arms active and erm climbing around in the hall is fun $[\ldots]$.

One of the key ways in which the school attempted to construct 'healthy' bodies was through physical education and exercise practices. Social processes and pedagogical techniques in PE lessons have previously been shown to demonstrate Foucault's disciplinary 
power at the level of the body through practices of 'surveillance', 'normalization', 'exclusion', 'classification', 'distribution', 'individualization', 'totalization' and 'regulation' (Gore, 1998). Similarly, in his work on PE in the last century, Kirk (1998) identified how schools used 'drilling' and 'inspecting' to regulate bodies suitable for military use. Moves towards universal adoption of the 'games ethic' and the provision of sport and games in public-funded schools in the early twentieth century, Kirk (1998) suggests, represented a 'looser' version of 'biopower' where bodily movements were regulated in less overt ways to encourage competition, power, winning, courage and heterosexuality. Gagen (2000) also discusses how boys were required to take part in 'healthy' competitive games in the early twentieth century playgrounds of Cambridge, Massachusetts in order to inculcate similar values.

In Meadow Junior, school practices clearly showed that qualities such as competition, courage, and self-confidence continued to be encouraged as part of a 'games ethic'. However, this ethic did appear to have been considerably modified to take account of wider socially inclusive education ideals and good citizenship practices, emphasising concepts such as participation, involvement, and good sportsmanship. These discourses were subtly inscribed onto children's bodies through practices such as celebrating sporting achievement during assembly and displaying relics of past sporting achievements around the school. Moderate competition was actively promoted as part of the PE curriculum, particularly in games, and some children showed strong motivation in such lessons, celebrating wins with group hugs and cheers. In the invasion games observed, individuals often got into disputes and arguments over whether rules had been broken and play had remained fair. This was moderated by teacher intervention in activities to encourage inclusion and ensure the 
involvement of all children (see research diary extract below), as well as verbally discouraging over-competitiveness.

I noticed that throughout the game, the class teacher was tending to use the rules a little selectively to help 'level the playing field'. For example, the 3 second rule was used more for active players, rather than those who rarely had possession of the ball.

(Research Diary Extract: Wednesday 5th April 2006)

These practices in $\mathrm{PE}$, combined with the other practices mentioned earlier in the playground, classroom and school in general, contributed to a discursive regime of 'healthism' that aimed to construct children's bodies as 'healthy'. These processes very much reflected dominant ideologies of childhood, where children are seen as subordinate dependents, in need of socialisation and guidance. As Valentine (2000) highlights, this ideology dictates that 'while adults are sexual, responsible, competent, strong, decision making agents; children are asexual, irresponsible, incompetent, vulnerable, human "becomings" in need of protection' (Valentine, 2000, pp. 257-258). Children are therefore considered as incapable of making their own health decisions, irrespective of their health knowledge, and in constant need of guidance from adults and the school.

\section{Children's Construction of a Discourse of Enjoyment}

Despite the emphasis and investment in a 'biopower of health' in the school, many children at Meadow Junior showed that they valued sport and active play for reasons other than 
health. In recent years, geographers have increasingly paid more attention to the significance of emotions in understanding social processes, particularly in the area of 'embodied geographies' (e.g. Longhurst, 2001; Dias, 2003; Davidson and Milligan, 2004). This development has been described as constituting an 'emotional turn' in Geography (Bondi et al., 2005) and promises to widen our understandings of how embodied emotions link and interconnect with wider social spaces. Emotional experiences were certainly important for children at Meadow Primary, such as Fleur and Zoe, who emphasised fun and enjoyment much more than health when giving reasons why they had chosen to take part in particular 'healthy' activities.

INTERVIEWER: Right erm, did you decide to do those things because they were healthy, or did you do them for a better reason?

FLEUR: Better reason.

ZOE: Better reason, 'cos they were fun.

FLEUR: Yeah.

INTERVIEWER: So both of you did them because they were fun?

FLEUR \& ZOE: Yeah.

FLEUR: Not because they're healthy, but fun.

ZOE: It's good that they are healthy as well.

Previous research in Australia revealed that children reflected two separate discourses in discussions about their sporting experiences, one being based around enjoyment and having fun with sport and the other based around more 'adult' discourses of participation, good citizenship and the need to be healthy (Macdonald et al., 2005). In a similar way, children in 
this study demonstrated the presence of a dual discourse of enjoyment and health. An initial answer of health as a motivation to take part in sport often developed into enjoyment as the conversation progressed. For many children, the concepts of 'fun' and 'health' were intrinsically connected in the context of sport and active play, and for others enjoyment proved to be the actual reason for taking part in activities, rather than health.

This finding is generally quite unsurprising, given that both qualitative (e.g. Mason, 1995; Mulvihill et al., 2000) and quantitative (e.g. Tuxworth, 1997; Burrows et al., 1999) studies have shown that fun and enjoyment is the most, or one of the most, important reasons for participating in sport and exercise for children. Indeed, in a questionnaire sample of 4059 year-olds, $85 \%$ of respondents ranked fun and enjoyment as the most significant reason for playing sports (Tuxworth, 1997). The same studies also showed that health and fitness were not as significant reasons for children to participate in sport, if they were even mentioned at all.

As well as activities outside of school, the fun and enjoyment factor for children was relevant for activities in school time. MacPhail et al. (2003) found that children aged 9-10 considered their conceptions of sport in school to be similar to their conceptions of sport outside of the school. Given the importance of pleasure and enjoyment for many children in talking about 'healthy activities' generally, it was therefore unsurprising to find that their experiences of sport and active play in school were also judged primarily on how enjoyable they had been.

INTERVIEWER: OK was there anything else that you enjoyed doing?

KATRINA: PE. 
NATALIE: The PE activity.

INTERVIEWER: OK. What did you enjoy about that?

KATRINA: Well it was ...

NATAALIE: It was fun.

KATRINA: Very fun and well very fun (laughs).

NATALIE: Yeah.

KATRINA: Fun and fun.

Although children all had different preferences regarding which sport and play activities they thought were fun, there were no examples of individuals who did not find any kind of formal or informal active pursuit enjoyable. Some children identified particular sports or activities that they enjoyed in PE lessons, or particular games that they liked to play on the playground. Others referred to certain sports as 'boring', or expressed a dislike of certain activities, such as going onto the field to do outdoor PE when it was muddy. Peter and Matt were keen to emphasise how much they enjoyed bench ball and football, but not dance.

INTERVIEWER: What do you really like about PE lessons?

PETER: Erm sometimes you get to play bench ball. Well it's fun and we're allowed to do stuff we don't get to do at home and in the class.

INTERVIEWER: OK.

MATT: Or when we play football like because it's er one bit of the day when you can just like run around and play a sport that you like.

$[\ldots]$

INTERVIEWER: Right and why don't you like doing [dance] stuff? 
MATT: Because it's girly stuff.

PETER: Because it's for girls.

Gender cultures, peer groups and other factors no doubt influenced some of these individual preferences. The point was, however, that sport, exercise and active play experiences were judged on their ability to be pleasurable or not, above their potential to be healthy or not, and these discourses created a mismatch between school and policy discourses of 'health'.

The emphasis that children placed on emotional geographies of enjoyment was not due to ignorance of health advice however. On the contrary, most children in the interviews showed a good knowledge of health issues, including healthy and unhealthy food and drink, and the importance of exercise compared with sedentary activities. Children's drawings confirmed this, showing 'healthy' characters eating fruit and drinking water, while taking part in a range of sports (see Figure 1). Although most of the activities were formal sports such as tennis and football, there were also examples of more informal activities such as skateboarding. In contrast, the 'unhealthy' characters were engaged in eating food high in fat or sugar, while taking part in activities like watching TV (see Figure 2). There was a strong corporeal theme evident in both sets of drawings and 'healthy' characters displayed thin or strong bodies, whereas 'unhealthy' characters were often portrayed as obese (see also Burrows and Wright, 2004). 

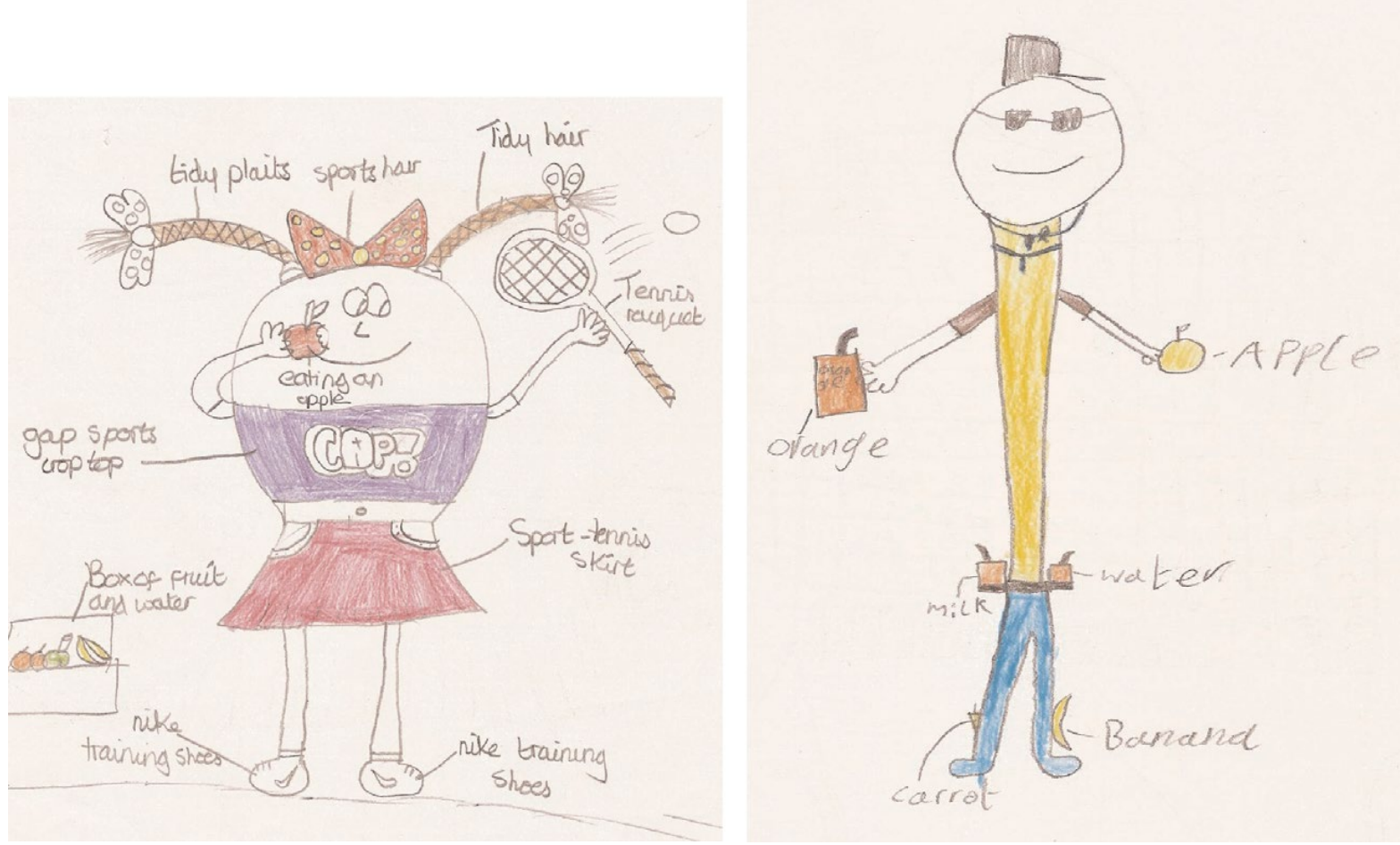

Figure 1. Healthy characters.
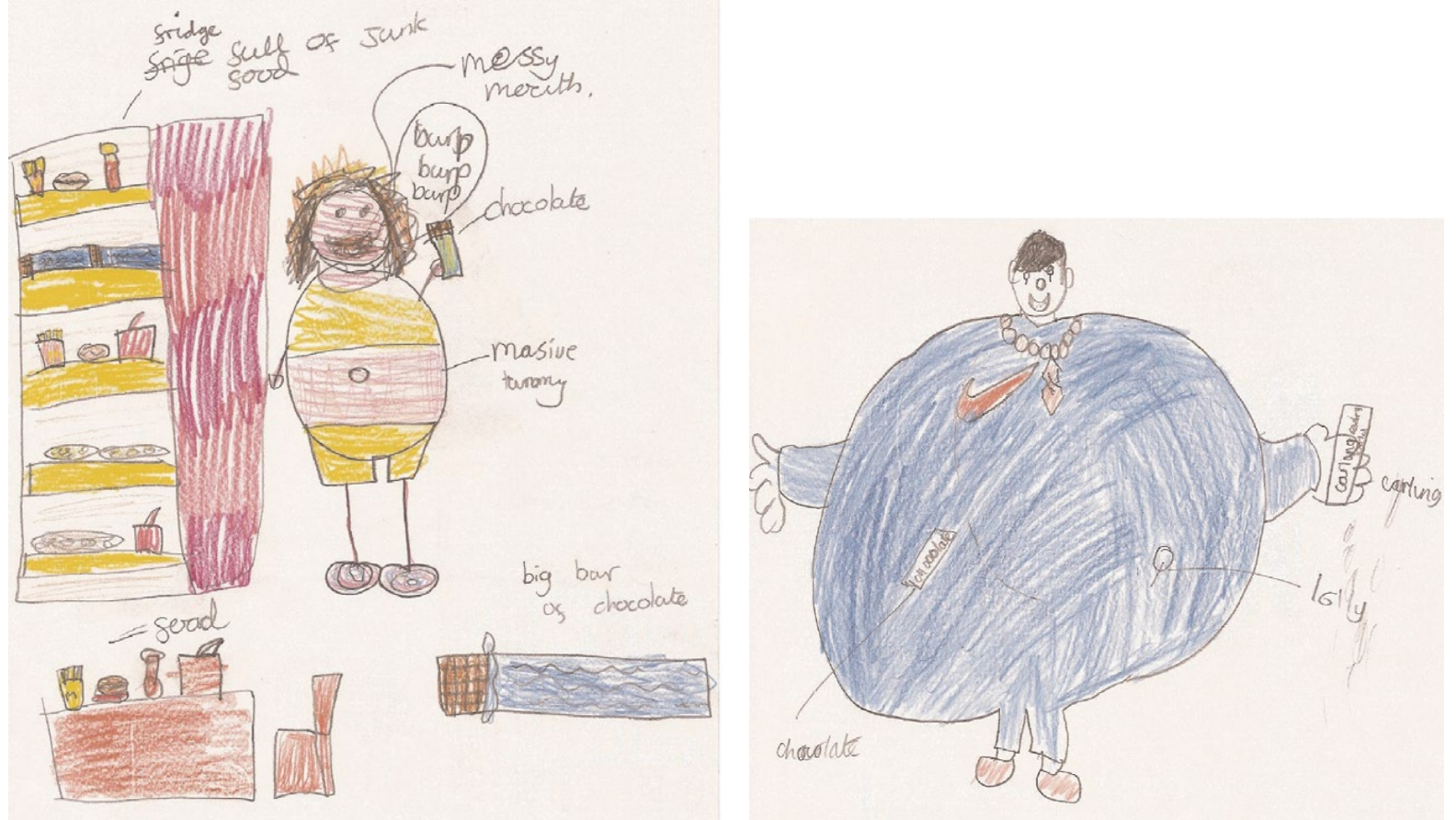

Figure 2. Unhealthy characters. 
In addition, the drawings highlighted the extent to which many children had 'bought in' to discourses regarding health and personality. Backett (1992, cited in Valentine, 1999b) points out that judgements about health can often become moral judgements about character. Burrows and Wright (2004) argue that children perceive health in terms of both physical and mental attributes and draw strong distinctions between 'healthy' and 'unhealthy'. It was interesting that the 'healthy' characters in the drawings tended to show neat and tidy characteristics, with fashionable clothes, hair and jewellery, and a desirable appearance. The 'unhealthy' characters, on the other hand, were portrayed as lazy and unattractive, lived in messy rooms and often had poor personal hygiene and cleanliness.

This 'pure' and 'impure' dichotomy was reinforced through some of the choices made for the photographs of healthy and unhealthy places around the school (see Figure 3). 'Healthy' places included gardens, open spaces and sites associated with 'fresh air', and appeared to be influenced by the 'rural idyll' where children's health is linked to purity and nature (see Jones, 1997). In contrast, 'unhealthy' places included dirty toilets and bins, and cupboards full of stale air, perhaps influenced by exclusionary discourses of dirt as a sign of inferiority (see Sibley, 1995b).
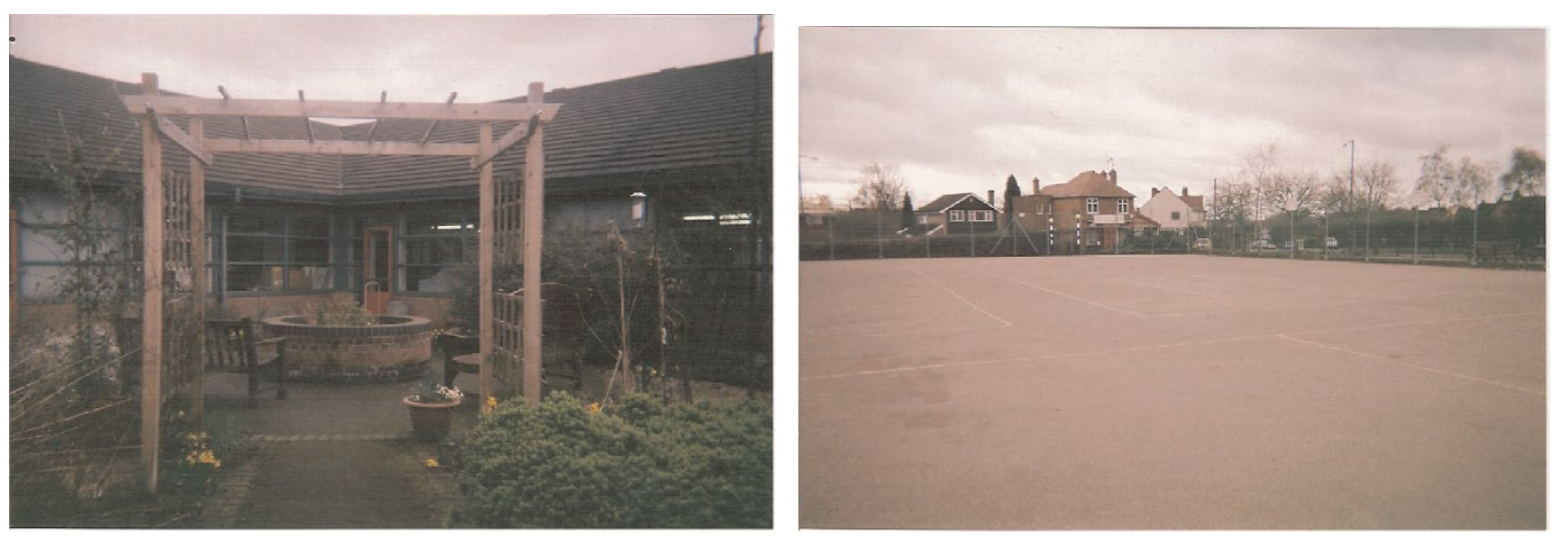

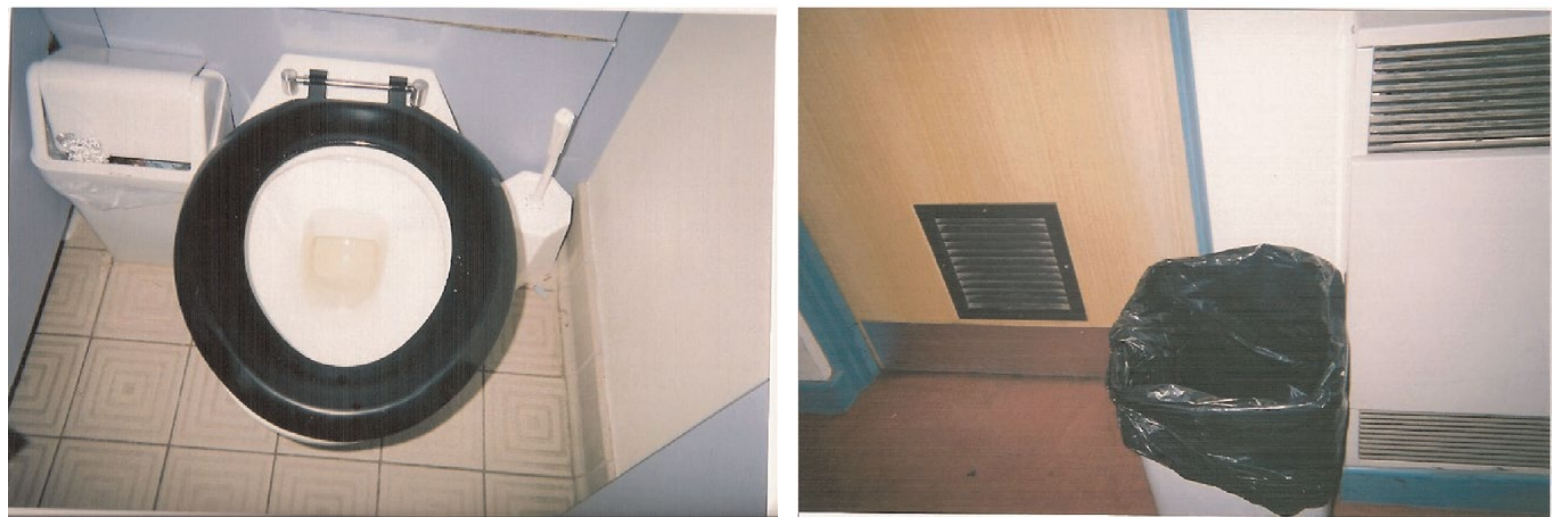

Figure 3. Healthy and unhealthy places.

Despite the high levels of knowledge regarding health issues and the strength of ideas about how health was associated with being a 'good' and 'bad' person, children still chose to put more emphasis on emotions. Fun and enjoyment were so important, that they were also integral to children's decisions regarding unhealthy activities such as eating unhealthy foods and watching TV. These choices were made even though children knew they were unhealthy. It was also interesting how many of the 'unhealthy' characters in the drawings appeared to be having just as much fun as the 'healthy' characters (see Figure 2).

INTERVIEWER: Yeah, why did you do those things even though you knew they were unhealthy?

FLEUR: 'Cos they looked nice.

ZOE: Because er, if you've had them before, you know what they taste like and they just taste gorgeous and erm yummy.

FLEUR: Can we stop talkin' about food now?!

INTERVIEWER: What about the TV, why did you do the TV?

ZOE: Why because. 
FLEUR: Because it's fun! You watch your favourite programs.

ZOE: It's fun and because that's the time to yourself.

Children's construction of an emotional discourse of enjoyment, in contrast to the school's discursive regime of 'healthism', could be explained by thinking about their decision-making processes. Previous work on adult eating practices has emphasised how, despite demonstrating a good awareness of the need to eat healthily, adults also thought it was important to 'let go' and take pleasure in food (Lupton, 1996). Many children in the study used similar justifications for their decision-making processes regarding healthy and unhealthy activities (see quote from Ryan below), showing pleasure and enjoyment to be central to these decisions, in the same way that they would be for adults (e.g. see Scanlan and Simons, 1992; Wankel, 1993). In highlighting the similarities between children's and adult's personal decision-making processes, these findings start to destabilise some of the dominant ideologies that define children as 'incompetent' and 'irresponsible' in contrast to 'rational' and 'knowledgeable' adults.

INTERVIWER: Oh right. So why did you do them then, even if you thought, even though they're unhealthy?

RYAN: You don't have to do healthy stuff all the time!

It is also useful to consider the reasons for the success or failure of health messages and advice in school. Holloway and Valentine (2003) demonstrated how many children were more interested in how using computers would affect their peer group standings, than government discourses of acquiring skills to get a 'good job' in the future. Similarly, children 
in the interviews did not seem to be overly concerned with health issues that were a long way in the future. On the other hand, anxieties about health can indeed be experienced by obese children who may suffer from bullying and exclusion or their own guilt and selfmonitoring (e.g. see Burrows et al., 2002). More research is therefore needed to investigate the real effects and relevance of health education on children's everyday lives.

In summary, emotions of pleasure and enjoyment were the main reasons for many children to value or not to value sport and exercise and the resultant discourses created by children created a mismatch with Government health discourses. Spaces of sport, exercise and active play in the school therefore became arenas of competing values and discourses that coexisted alongside each other. In this way, it was children's values and emotions that acted as foundations for the alternative discourses that influenced transformation of the institution.

\section{Contesting Power and Renegotiating the Institution}

In addition to contesting corporeal regimes in school through their emotional expressions and discourses of enjoyment, many children also challenged 'bio-power' through physical bodily practices. In this way, meanings of the body constructed by the institution were renegotiated through children's own agency. Children achieved this by displaying alternative bodily practices that employed sport, exercise and active play as technologies of subversion, thus destabilising their 'healthy' meanings. Constructions of the 'disciplined' and 'civilised' body and the associated desirable behaviours promoted in the school were therefore contested using bodies. 
Fielding (2000) describes the school as "a "hot bed" of moral geographies-of moral codes about and where children ought to learn and behave' (Fielding, 2000, p. 231). School practices are therefore designed to teach children how to demonstrate 'civilised' bodies, through their internalisation of acceptable ways of using their body and 'morally good behaviours' (see Elias, 1978). These processes represent yet another form of 'biopower' designed to construct children's bodies as 'disciplined' and docile through discursive corporeal regimes and could be seen working on a daily basis at Meadow Junior. In the classroom, children were required to sit quietly in their seats while listening to the teacher or carrying out independent tasks at their desks. On the playground, adults set rules for where children were permitted to go and what activities they could take part in.

Aside from talking when they were not supposed to, children's main way of challenging these rules and procedures was to use physical skills. In this way, sport and physical education was effectively taken into the classroom and around the school in general, to contest notions of the 'disciplined' body. When the teachers were not looking, I observed children throwing rubbers, flicking pencils, duelling with rulers, running in corridors, swinging on chairs, walking around when they had been asked to sit down and so on. My favourite example was Danny, who decided to do a press-up across the top of his classroom table and chair, after hearing the PE lesson would be on fitness aerobics. Peter and Matt also talked about some of the times they had used physical activity in school to challenge rules, emphasising the enjoyment they experienced in doing so.

INTERVIEWER: Yeah OK. Are there any places here where you do fun things even though you're not supposed to? 
PETER: The corridor.

INTERVIEWER: What happens in the corridor?

PETER: We play tag and play rugby and stuff.

INTERVIEWER: OK.

MATT: I think the classroom 'cos we're always like messin' about, playin' like hockey in there and stuff.

INTERVIEWER: Hockey in the classroom!?

MATT: With rulers.

Many children frequently used active play on the playground to further challenge constructions of the 'disciplined' body. Previous research has shown how children demonstrate active agency in the school playground (e.g. see Factor, 2004; Thompson, 2005), and Meadow Junior was no exception. Playground equipment intended to be used for 'healthy' and 'structured' play was often used in alternative ways. Tennis rackets were sometimes used to knock against a fence, skipping ropes were used to tie up other children, and tennis balls were used as footballs. Individuals would use tennis balls or smaller rubber balls from home to play football on days when they should not have been playing, sometimes before being asked to stop by playground supervisors (see research diary extract below). In this way, the meaning of the equipment was subverted and contested by children's corporeal practices.

I saw lots of tennis balls being used for football, despite the ban, and a boy swing a rope around in a way that was clearly different to its intended use! 
The existence of acts of corporeal resistance discussed above meant that disciplinary methods and techniques were required in school to maintain order and a productive learning environment. What was particularly interesting, however, was the way that children's own meanings and discourses fed into this process, modifying and renegotiating the practices in school and the way in which the discursive regimes operated. Responding to the kind of challenges to constructions of the 'civilised body' that I discussed above, the class teacher at Meadow Junior used children's discourses of enjoyment in sport and active play to help maintain discipline, motivation and enthusiasm in the classroom. The first strategy involved using enjoyment in sport as a currency to 'buy' children's co-operation and the second one entailed using active fun to enrich the curriculum.

Knowing that sport, exercise and active play were valued so highly by most children in the class, these activities were used as motivating factors to encourage children to work hard during the less exciting parts of the school day. Children were under the impression that if they worked hard and behaved well, there would be more chance that they would get the opportunity to play fun games in PE (although in reality, much of the PE curriculum was compulsory). Individuals also attempted to sway the teacher's decisions by requesting particular sports or activities. When these requests were taken into account, this led children to believe they had some influence over the PE curriculum.

INTERVIEWER: Do you choose which PE you do? 
KERRY: Well sometimes we do 'cos like say when we were playin' bench ball before, it was our choice because everyone had wanted to play bench ball for a long time, since the benches were left out ever since Mrs. T's did a PE lesson erm but then Mr. K. wanted to get this dance done and he said if we got it done and we were sensible, then we could play bench ball.

INTERVIEWER: Right OK.

BRITNEY: So really if we're good the first lesson, then the next lesson you can do what you want really.

INTERVIEWER: Yeah.

Similarly, if children did not co-operate and behave well, an effective consequence to discourage such behaviour was to withdraw fun and enjoyable sports and active play. Children who behaved badly could find themselves losing break time and active play on the playground, and if the whole class failed to co-operate during PE, the lesson could be stopped and children returned to the classroom. This did not happen during the study period, but Kerry, Britney and Tommy discussed their dislike of having the fun PE lesson removed during an interview.

KERRY: Erm well sometimes there can be a few people that.

BRITNEY: Spoil it.

KERRY: Yeah and we sometimes have to go back to class or erm well PE's mostly really good.

BRITNEY: But like it's just the time when we line up, people, some people spoil it by shoutin' out and erm don't do what Mr. K. says for us to do. 
INTERVIWER: OK.

TOMMY: So we don't go out.

BRITNEY: And like, some people mess about during PE and then we have to go in.

In this way, the enjoyment of sport, exercise and active play became a kind of currency, used to barter for children's co-operation and good behaviour by the school. For the part of the children, their currency was their co-operation and good behaviour, which if given in plentiful enough supply (or so they believed), would lead to pleasure and enjoyment, often in the form of sport, exercise or active play. The disadvantage of this approach was the way that it effectively polarised PE and other forms of physical activity as separate from the rest of the curriculum, which by its very definition was then perceived as boring and uninteresting.

There was, however, a second way that the school used the concept of enjoyment to motivate and encourage children. Sport and active play was sometimes used to enrich lessons that may otherwise have been seen by children as dull and boring, thus keeping their attention and helping to direct learning. This was achieved either by using the concept of sport to make lessons more interesting (e.g. discussing the loss of outdoor urban play space in Geography), or through the use of kinaesthetic learning. This is where children's learning is aided through doing rather than merely seeing or hearing. There are many techniques and activities that schools sometimes use to promote this type of learning (see e.g. Gardner, 1993; Smith et al., 2003). At the study school, 'brain exercises' were used in assembly once a week. These involved children taking part in very short physical activities, such as stretching 
and twisting, and crossing different parts of their body in order to help concentration and focus their minds on the tasks in hand.

Taking the concept of enjoyment more widely and applying it to a lesson had the same enriching effect. In one of the lessons that the class teacher taught in PE, he was able to make the experience more enjoyable simply by his own involvement in leading it.

INTERVIEWER: Right OK, well you've said that you really enjoyed the PE. Why was that?

FLEUR: Erm I like the music side of it. I like the way erm Mr. K. started dancin'. It was quite funny.

ZOE: And how he got everyone to do it and everyone joined in, so he made it fun for us.

In summary, children were able to change the way that the institution operated, if in a small way, as a result of their corporal practices of resistance and the alternative meanings, values and discourses that they brought to practices in the school. The children's emotions of pleasure and enjoyment were fed back into the discursive regimes of the school, as part of the disciplinary mechanisms that exerted power over children's bodies. Of course, this process also highlights the role of teachers in adapting institutional practices in response to children's understandings. In this way, children's own values, practices and discourses, along with the teacher's responses to these, were able to renegotiate the institution. 


\section{Conclusion}

Government health policy messages and programmes in the UK, and the resultant schemes and practices in school relating to sport, exercise and active play, worked towards constructing children's bodies as 'healthy'. This was achieved through health messages in the curriculum, Physical Education, extra-curricular sport and provision for active play on the playground. Children in Meadow Junior demonstrated a good understanding of health but despite this, their decisions on how to spend their time often led them to value fun and enjoyment much more highly, reinterpreting Government and school messages in a more critical and active way. This highlighted the way that children's decision-making processes are much more adult-like than adults often give them credit for, destabilising dominant ideologies that see children as incompetent. Children therefore understood school sport, exercise and active play through their emotional experiences of pleasure and enjoyment, creating alternative discourses that intersected and mingled with hegemonic ones in school spaces.

In addition to challenging discursive regimes in school through alternative emotional discourses, children also demonstrated social agency in the way that they contested power through the use of their bodily practices. By using sport and active play to challenge constructions of the 'civilised' and 'disciplined' body, they were able to subvert the meaning of 'healthy' sport and active play in school. These practices effectively fed back into the working of the institution, creating a need to respond and use children's own reformulation of sport and active play as fun and enjoyment to maintain institutional power. Enjoyment was thus used both as a 'currency' to 'buy' children's co-operation as well as a strategy for 
enrichment to increase children's motivation and engagement in their learning. This underlined the fluid and porous nature of the institution, while illustrating children's own ability to renegotiate school spaces.

One of the key points highlighted in this article, is the diverse ways in which children demonstrated their agency in an institutional context. Not only did they challenge discursive regimes in the school through the use of their own bodily practices, but also through the employment of emotional discourses. Both of these creative expressions of agency worked to contest dominant ideologies of childhood that see children as passive and incompetent in society. By considering some of the ways in which institutional and children's geographies intersect, I have attempted to show how an examination of different spatial contexts can deepen our understanding of how children experience and create their own social worlds. The findings also highlight the need for children's geographers to pay more attention to the issue of emotions, which have an important role in structuring children's understandings and experiences within everyday spaces.

In terms of policy, the findings of this study offer 'food for thought' for all Western Governments involved in constructing school-based health initiatives. By taking enjoyment more seriously and encouraging children to take part in sport, exercise and active play activities that they enjoy, rather than doing them for health reasons, the findings suggest that schools are more likely to help children to find activities that they can continue to enjoy once they have left education. Given the vast majority of adults take part in individual or paired sport or recreational activities for fun, rather than team sports (see Office for National Statistics, 2004), perhaps schools need to review the balance of their PE curriculum 
to remove the overemphasis on team games and work towards providing children with a broader experience of different types of sports and active pursuits. A bigger focus on enjoyment may give children the motivation to continue these activities after their time in school and could lead to healthier adult lifestyles.

Finally, the study also suggests a need for further research into sport and active play outside of school. This might involve a focus on children's journeys to school, where walking or cycling could provide a beneficial means of tackling childhood obesity issues (e.g. see Kearns et al., 2003), or more informal kinds of exercise such as gardening and conservation. The fact that all children in the study enjoyed some form of exercise or active play, whether formal or informal, perhaps highlights the benefits of the more unstructured approach that primary schools take towards exercise compared with secondary schools. The way in which policy makers conceive and promote sport and exercise to children generally is also, therefore, a potentially fruitful area of research.

\section{Acknowledgements}

I would like to thank Gill Valentine for very helpful comments on earlier drafts of the article, Sarah Irwin and Gill Valentine for their advice and support during the research project on which this article draws, and two anonymous referees for their suggestions. I am grateful to ESRC for the opportunity to have undertaken the study. Many thanks also to the all the staff and children at the case study school who contributed to the research. 


\section{Note}

1. Butler (1993) rejects the notion that discursive regimes are able to externally 'construct' bodies and subjects, arguing instead that bodies are materialized through individuals' repetitive performances of regulatory norms and practices. According to Butler (1993), subjects are enabled by discursive performativity and citational practice so agency can therefore be located as a rearticulatory practice, rather than seen in opposition to external power. Although this framework has been useful in making sense of regulatory frameworks concerned with social identity (e.g. Gagen, 2000), Butler's work leaves little room for intentional resistance and subversion from social agents in a way that is illustrated in this article (e.g. see Rose, 1996).

\section{References}

Alderson, P. (1995) Listening to Children: Children, Ethics and Social Research, Ilford: Barnardo's.

Alderson, P. (2000) Children as researchers: The effects of participation rights on research methodology, in: P. Christensen and A. James (eds) Research with Children: Perspectives and Practice, London: Falmer, 241-257. 
Alderson, P. (2004) Ethics, in: S. Fraser, V. Lewis, S. Ding, M. Kellet and C. Robinson (eds) Doing Research with Children and Young People, London: Sage, 97-112.

Alderson, P. and Morrow, V. (2004) Ethics, Social Research and Consulting with Children and Young People, Iford: Barnado's.

Barnes, T.J. and Duncan, J.S. (1992) Introduction, in: T.J. Barnes and J.S. Duncan (eds) Writing Worlds: Discourse, Text and Metaphor in the Representation of Landscape, London and New York: Routledge, 1-17.

Barrett, M. (1991) The Politics of Truth: From Marx to Foucault, Cambridge: Polity Press.

Boden, D. (1994) The Business of Talk: Organisations in Action, Cambridge: Polity Press.

Bondi, L., Davidson, J. and Smith, M. (eds) (2005) Introduction: Geography's 'emotional turn', in: Emotional Geographies, Aldershot: Ashagate, 1-16.

Bourdieu, P. (1990) The Logic of Practice, Cambridge: Polity Press.

Burrows, L. and Wright, J. (2004) The good life: New Zealand children's perspectives on health and self, Sport, Education \& Society, 9(2), 193-205.

Burrows, C., Eves, F. and Cooper, D.M. (1999) Children's perceptions of exercise: Are children mini-adults?, Health Education, 99(2), 61-69. 
Burrows, L., Wright, J. and Jungersen-Smith, J. (2002) 'Measure your belly': New Zealand children's constructions of health and fitness, Journal of Teaching in Physical Education, 22(1), 20-38.

Butler, J.P. (2003) Bodies that Matter: On the Discursive Limits of 'Sex', London: Routledge.

Davidson, J. and Milligan, C. (2004) Embodying emotion, sensing space: Introducing emotional geographies, Social and Cultural Geography, 5(4), 523-532.

Department of Health (2005) National Healthy Schools Status: A Guide for Schools, London: DoH.

Department of Health (2006) Health Challenge England: Factsheet on Obesity, London: DoH.

Dias, K. (2003) The ana sanctuary: Women's pro-anorexia narratives in cyberspace, Journal of International Women's Studies, 4(2), 31-45.

Elias, N. (1978) [1939 original] The Civilizing Process, Vol. 1: The History of Manners, Oxford: Basil Blackwell.

Evans, B. (2006) 'I'd feel ashamed': Girls' bodies and sports participation, Gender, Place and Culture, 13(5), 547-561. 
Every Child Matters Website www.everychildmatters.gov.uk (accessed 10/7/2006).

Factor, J. (2004) Tree stumps; manhole covers and rubbish tins: The invisible play-lines of a primary school playground, Childhood, 11(2), 142-154.

Ferre', M.B., Guitart, A.O. and Ferrer, M.P. (2006) Children and playgrounds in Mediterranean cities, Children's Geographies, 4(2), 173-183.

Fielding, S. (2000) Walk on the left!: Children's geographies and the primary school, in: S.L. Holloway and G. Valentine (eds) Children's Geographies: Playing, Living, Learning, London: Routledge, 230-244.

Foucault, M. (1972) The Archaeology of Knowledge, London: Tavistock.

Foucault, M. (1977) Discipline and Punish: The Birth of the Prison, London: Penguin.

Foucault, M. (1979) The Will to Knowledge: The History of Sexuality Vol. 1, London: Penguin.

Gagen, E.A. (2000) Playing the part: Performing gender in America's playgrounds, in: S.L. Holloway and G. Valentine (eds) Children's Geographies: Playing, Living, Learning, London: Routledge, 213-229.

Gardner, H. (1993) Multiple Intelligences: The Theory in Practice, New York: Basic Books. 
Gore, J. (1998) Disciplining bodies: On the continuity of power relations in pedagogy, in: T. Popkewitz and M. Brennan (eds) Foucault's Challenge: Discourse, Knowledge and Power in Education, New York: Teacher's College Press, 231-251.

Gregory, D. (2000) 'Discourse', in: R.J. Johnston, D. Gregory, G. Pratt and M. Watts (eds) The Dictionary of Human Geography, 4th edition, Oxford: Blackwell, 180-181.

Grosz, E. (1993) Bodies-cities, in: B. Colomina (ed.) Sexuality and Space, New York: Princeton Architectural Press.

HM Government (2004) Choosing Health: Making Healthy Choices Easier, London: The Stationery Office.

Holloway, S.L. and Valentine, G. (eds) (2000) Children's geographies and the new social studies of childhood, in: Children's Geographies: Playing, Living, Learning, London: Routledge, 1-28.

Holloway, S.L. and Valentine, G. (2001) Children at home in the wired world: Reshaping and rethinking home, Urban Geography, 22(6), 562-583.

Holloway, S.L. and Valentine, G. (2003) Cyberkids: Children in the Information Age, London: RoutledgeFalmer. 
Holloway, S.L., Valentine, G. and Bingham, N. (2000) Institutionalising technologies: Masculinities, femininities, and the heterosexual economy of the IT classroom, Environment and Planning A, 32(4), 617-633.

Holt, L. (2004) Children with mind-body differences: Performing disability in primary school classrooms, Children's Geographies, 2(2), 219-236.

Hyams, M.S. (2000) 'Pay attention in class ... [and] don't get pregnant': A discourse of academic success among adolescent Latinas, Environment and Planning A, 32(4), 635-654.

Jones, O. (1997) Little figures, big shadows: Country childhood stories, in: P. Cloke and J. Little (eds) Contested Countryside Cultures: Otherness, Marginalisation and Rurality, London: Routledge, 158-179.

Joyce, P. (2003) The Rule of Freedom: Liberalism and the Modern City, London: Verso.

Karsten, L. (2003) Children's use of public space: The gendered world of the playground, Childhood, 10(4), 457-473.

Kearns, R.A., Collins, D.C.A. and Neuwelt, P.M. (2003) The walking school bus: Extending children's geographies?, Area, 35(3), 285-292.

Kirk, D. (1998) Schooling Bodies: School Practice and Public Discourse 1880-1950, London: Leicester University Press. 
Lindsay, G. (2000) Researching children's perspectives: Ethical issues, in: A. Lewis and G. Lindsay (eds) Researching Children's Perspectives, Buckingham: Open University Press, 3-20.

Longhurst, R. (2001) Bodies: Exploring Fluid Boundaries, London and New York: Routledge.

Lupton, D. (1996) Food, The Body and The Self, London: Sage.

Macdonald, D., Rodger, S., Abbott, K., Ziviani, J. and Jones, J. (2005) 'I could do with a pair of wings': Perspectives on physical activity, bodies and health from young Australian children, Sport, Education \& Society, 10(2), 95-209.

Macphail, A., Kinchin, G. and Kirk, D. (2003) Students' conceptions of sports and sport education, European Physical Education Review, 9(3), 285-299.

Mason, J. (2002) Qualitative Researching, 2nd edition, London: Sage.

Mason, V. (1995) Young People and Sport in England 1994: The Views of Teachers and Children, London: Sports Council.

Massey, D. (1999) Spaces of politics, in: D. Massey, J. Allen and P. Sarre (eds) Human Geography Today, Cambridge: Polity Press. 
Matthews, H., Limb, M. and Taylor, M. (1998) The geography of children: Some ethical and methodological considerations for project and dissertation work, Journal of Geography in Higher Education, 22(3), 311-324.

Matthews, H., Limb, M. and Taylor, M. (2000) The 'street as thirdspace', in: S.L. Holloway and G. Valentine (eds) Children's Geographies: Playing, Living, Learning, London: Routledge, $63-79$.

Mayall, B. (2000) Conversations with children: Working with generational issues, in: P.

Christensen and A. James (eds) Research with Children: Perspectives and practices, London: RoutledgeFalmer, 120-135.

Mayall, B., Bendelow, G., Barker, S., Storey, P. and Veltman, M. (1996) Children's Health in Primary Schools, London: Falmer.

Mcnamee, S. (1998) The home: Youth, gender and video games: Power and control in the home, in: T. Skelton and G. Valentine (eds) Cool Places: Geographies of Youth Cultures, London: Routledge, 195-206.

Mills, S. (1997) Discourse, London and New York: Routledge.

Mulvihill, C., Rivers, K. and Aggleton, P. (2000) A qualitative study investigating the views of primary-age children and parents on physical activity, Health Education Journal, 59(2), 166179. 
National PE Strategy Website

www.teachernet.gov.uk/teachingandlearning/subjects/pe/nationalstrategy (accessed $1 / 6 / 2006)$.

Office for National Statistics (2004) Sport and Leisure: Results from the Sport and Leisure Module of the 2002 General Household Survey, London: Office for National Statistics.

O’Neill, P. and Gibson-Graham, J.K. (1999) Enterprise discourse and executive talk: Stories that destabilise the company, Transactions of the Institute of British Geographers, 24(1), 1122.

Ontario Ministry of Education Website www.edu.gov.on.ca/eng/teachers/healthyschools.html (accessed 24/11/2006).

Philo, C. and Parr, H. (2000) Institutional geographies: Introductory remarks, Geoforum, $31(4), 513-521$.

Prout, A. and James, A. (1997) A new paradigm for the sociology of childhood', in: A. James and A. Prout (eds). Constructing and Reconstructing Childhood: Contemporary Issues in the Sociological Study of Childhood, $2^{\text {nd }}$ edition, London: Falmer Press, 7-33. 
Punch, S. (2000) Children's strategies for creating playspaces: Negotiating independence in rural Bolivia, in: S.L. Holloway and G. Valentine (eds) Children's Geographies: Playing, Living, Learning, London: Routledge, 48-62.

Rawlins, E. (in press) Citizenship, health education and the UK obesity 'crisis', $A C M E, 7(1)$.

Raco, M. (2003) Governmentality, subject-building and the discourse and practices of devolution in the UK, Transactions of the Institute of British Geographers NS 28, 75-95.

Richardson, L. (1994) Writing: A method of inquiry, in: N.K. Denzin and Y.S. Lincoln (eds) Handbook of Qualitative Research, Thousands Oaks, CA: Sage, 444-462.

Robson, E. and Ansell, N. (2000) Young carers in Southern Africa: Exploring stories from Zimbabwean secondary school students, in: S.L. Holloway and G. Valentine (eds) Children's Geographies: Playing, Living, Learning, London: Routledge, 174-193.

Rose, G. (1996) As if the mirrors had bled: Masculine dwelling, masculinist theory and feminist masquerade, in: N. Duncan (ed.) BodySpace, London: Routledge, 56-74.

Rose-Redwood, R.S. (2006) Governmentality, geography, and the geo-coded world, Progress in Human Geography, 30(4), 469-486.

Saugeres, L. (2000) Of tidy gardens and clean houses: Housing officers as agents of social control, Geoforum, 31(4), 587-599. 
Scalan, T.K. and Simons, J.P. (1992) The construct of sport enjoyment, in: G.C. Roberts (ed.) Motivation in Sport and Exercise, Champaign, IL, Human Kinetics Books, 199-215.

Scratz, M. and Steiner-Loffler, U. (1998) Pupils using photographs in school self-evaluation, in: J. Prosser (ed.) Image-Based Research: A Sourcebook for Qualitative Researchers, London: RoutledgeFalmer, 235-251.

Sibley, D. (1995a) Families and domestic routines: Constructing the boundaries of childhood', in: S. Pile and N. Thrift (eds) Mapping the Subject: Geographies of Cultural Transformation, London: Routledge, 123-137.

Sibley, D. (1995b) Geographies of Exclusion: Society and Difference in the West, London: Routledge.

Smith, A., Lovatt, M. and Wise, D. (2003) Accelerated Learning: A User's Guide, Stafford: Network Educational Press.

Thompson, J.B. (1981) Critical Hermeneutics, Cambridge: University Press.

Thompson, J.B. (1984) Studies in the Theory of Ideology, Cambridge: Polity Press.

Thompson, S. (2005) 'Territorialising' the primary school playground: Deconstructing the geography of playtime, Children's Geographies, 3(1), 63-78. 
Thompson, J.L. and Philo, P. (2004) Playful spaces? A social geography of children's play in Livingston, Scotland, Children's Geographies, 2(1), 111-130.

Tooke, J. (2000) Institutional power geometries: Enduring and shifting work relations in cleansing depots, Geoforum, 31(4), 567-574.

Tuxworth, B. (1997) The St. Edmundsbury Fitness Survey 1993-1995, Bury St. Edmunds: St. Edmundsbury Borough Council.

US Department of Education Website www.ed.gov/news/pressreleases/2004/09/09282004.html (accessed 24/11/2006).

Valentine, G. (1997) 'Oh yes I can', 'Oh no you can't', Children and parents' understandings of kids' competence to negotiate public space safely, Antipode, 29(1), 65-89.

Valentine, G. (1999a) Being seen and heard? The ethical complexities of working with children and young people at home and at school, Ethics, Place and Environment, 2(2), 141155.

Valentine, G. (1999b) Imagined geographies: Geographical knowledges of self and other in everyday life, in: D. Massey, J. Allen and P. Sarre (eds) Human Geography Today, Cambridge: Polity Press, 47-61. 
Valentine, G. (2000) Exploring children and young people's narratives of identity, Geoforum, $31(2), 257-267$.

Victoria Department of Education and Training Website www.education.vic.gov.au/about/directions/goforyourlife.htm (accessed 24/11/2006).

Wankel, L.M. (1993) The importance of enjoyment to adherence and psychological benefits from physical activity, International Journal of Sport Psychology, 24(2), 151-169.

Wetten, N.M. and Mcwhirter, J. (1998) Images and curriculum development in health education, in: J. Prosser (ed.) Image-Based Research: A Sourcebook for Qualitative Researchers, London: RoutledgeFalmer, 263-283.

Wright, J. and Burrows, L. (2004) 'Being healthy': The discursive construction of health in New Zealand children's responses to the National Education Monitoring Project, Discourse: Studies in the Cultural Politics of Education, 25(2), 11-30.

Yin, R.K. (2003) Case Study Research: Designs and Methods, 3rd edition, London: Sage. 